\title{
An Odontometric Investigation of Canary Islander Origins
}

\author{
Joel D. Irish* and Brian E. Hemphill ${ }^{\text {** }}$ \\ "Department of Anthropology, University of Alaska, Fairbanks, AK 99775. \\ "Department of Sociology \& Anthropology, California State University, Bakersfield, CA 93311
}

ABSTRACT Attempts by anthropologists to account for the peopling of the Canary Islands have led to theories that call for one, two, and even four immigration events. However, most agree the Canary Island Guanche are biologically closest to Berbers from Morocco and Algeria. Genetic contributions from Arabs, Romans, and Carthaginians have also been proposed. An earlier study by Irish using Penrose analysis of odontometric data in samples of Guanche, Shawia and Kabyle Berbers, and Bedouin Arabs supports many of these proposed genetic relationships.

The present investigation expands upon this earlier work by adding samples of Carthaginians, Egyptians, and Nubians, and by using tooth size apportionment analysis, a more robust statistical approach for

The Canary Islands are located in the Atlantic Ocean off the northwest coast of Africa (Fig. 1). Seven small islands comprise the archipelago: La Palma, Gomera, Hierro, Tenerife, Grand Canaria, Fuerteventura, and Lanzarote. Of the seven islands, Fuerteventura is nearest the continent, approximately $100 \mathrm{~km}$ west of Cape Juby, Morocco. The Canary Islands have been a part of Spain since the late 15th century. However, prior to that time they were occupied by the Guanche - the aboriginal inhabitants of the archipelago. These early people were primarily cereal agriculturalists who practiced a Neolithic lifestyle (Cavalli-Sforza et al., 1994). They possessed domesticated goats and pigs, and supplemented their diet with shellfish, fish, and various wild plants (Mercer, 1980).

Authors' note: A preliminary version of this paper was included in the 2001 volume La Paléo-Odontologie: Analyses et Méthodes d'Étude, Paris: Éditions Artcom, edited by Djillali Hadjouis and Bertrand Mafart. That article (Irish and Hemphill, 2001) was published in French, is generally not available outside of western Europe, and contained several publisher errors in the tables and figures. As such, we decided to provide a modified and expanded English translation to facilitate dissemination of our findings to a wider audience of dental and Canary Island researchers. assessing inter-sample differences in the distribution, or allocation, of tooth size in the maxillary and mandibular dental arcades. The analysis yielded three components that account for $>80 \%$ of the total variance. Cluster analysis and three-dimensional ordination of group component scores provide additional insight into Canary Island/North African relationships. Except for one early Nubian sample, the Guanche exhibit some measure of affinity to all others. However, they are most like Berbers and Carthaginians. These results suggest that Canary Islanders belong to a greater North African gene pool, yet show the closest affinities to Northwest Africans - which corroborates earlier dental and nondental findings. Dental Anthropology 2004;17:8-17.

Over the past 100 years, numerous researchers have attempted to determine the origins and biological affinities of the Guanche (e.g., Verneau 1887, 1891; Hooton 1916, 1925; Falkenburger 1939; Fusté 1959, 1965; Schwidetzky 1963; Roberts et al., 1966; Vallois 1969; Mercer 1980; Gonzalez and Tejera, 1981; Onrubia Pintado, 1987; Bermudez de Castro, 1989). As a result, the original Guanche homeland has alternately been identified as Africa, Europe, and/or the eastern Mediterranean area. The purpose of the present investigation is to reexamine four of these origins hypotheses using evidence from principal components analysis of odontometric data in Canary Island, North African, and West Asian-derived samples. Although other theories exist (see Vallois 1969 for an overview), the four examined here afford a representative sampling of those envisioned by all researchers. Components obtained from statistical analyses yield information on overall crown size, as well as the allocation of size across dimensions and tooth types in both jaws among samples. This approach, termed tooth size apportionment analysis (see Harris and Bailit, 1988; Harris and Rathbun, 1991; Lukacs and Hemphill, 1993),

Address for correspondence: Joel D. Irish, Department of Anthropology, P.O. Box 757720, University of Alaska Fairbanks, Fairbanks, AK 99775-7720, U.S.A.

E-mail: ffjdi@uaf.edu 
is intended to provide new insight into the old problem of understanding Guanche ancestry.

\section{PREVIOUS PEOPLING HYPOTHESES}

Hooton (1916, 1925) was one of several early anthropological researchers to investigate the origins and population history of Canary Islanders (see also Verneau 1887, 1891, and among others, Quatrefages and Hamy 1874, Shrubsall 1896, von Luschan 1896, von Behr 1908 (as presented in Vallois 1969)). He hypothesized that four migrations to the islands from North Africa took place during the Neolithic and Bronze Age. Based on the analyses of craniometric and ethnographic data, Hooton maintained that the Guanche were comprised of different stocks of people largely exhibiting Mediterranean and Alpine Caucasoid components, supplemented perhaps, by sub-Saharan and other elements. He further proposed that they originated from populations inhabiting southern Morocco, the Atlas Mountains of northern Morocco and Algeria, and the eastern Mediterranean (Fig. 1). Subsequent intermixture among these four groups, along with later Arab, Berber, and Carthaginian gene flow, was thought to have resulted in the pre-European Contact peoples of the Canary Islands.

Based on cranial morphometric data, Schwidetzky (1963) envisioned two migrations from the adjacent
African mainland during the Neolithic. These two groups consisted of "Cro-Magnoid" and "Mediterranean-like" cranial types, asserted to be evident in prehistoric Guanche remains. These same findings are echoed by Fusté $(1959,1965)$, Vallois (1969), and others. The former cranial type is said to be characterized by a wide low face with robust features, whereas the latter is more gracile with a narrow, high face.

Roberts and coworkers (1966) proposed that the Guanche were the product of an ancient colonization from Europe (which reprises Verneau's thesis to some extent (see Vallois 1969)). They based their conclusions on perceived osteological affinities of ancient Guanche skeletons (per Hooton, 1925; Hiernaux, 1975) and serological and dermatoglyphic affinities of living Canary Islanders (Mourant, 1954; Roberts et al., 1966) to Northwest Europeans.

Lastly, Mercer (1980) described an immigration of Northwest African Berbers during the Roman era, based on 15th-17th century ethnographic accounts of Guanche oral traditions and paleo-serological analyses of Guanche mummies. He suggested that Berber malcontents from the Atlas Mountains of northern Morocco and Algeria were exiled to the islands as punishment for resistance to Roman rule. Mercer also sees a lack of definite radiocarbon dates prior to the first century $\mathrm{AD}$ in the archipelago as supportive of this

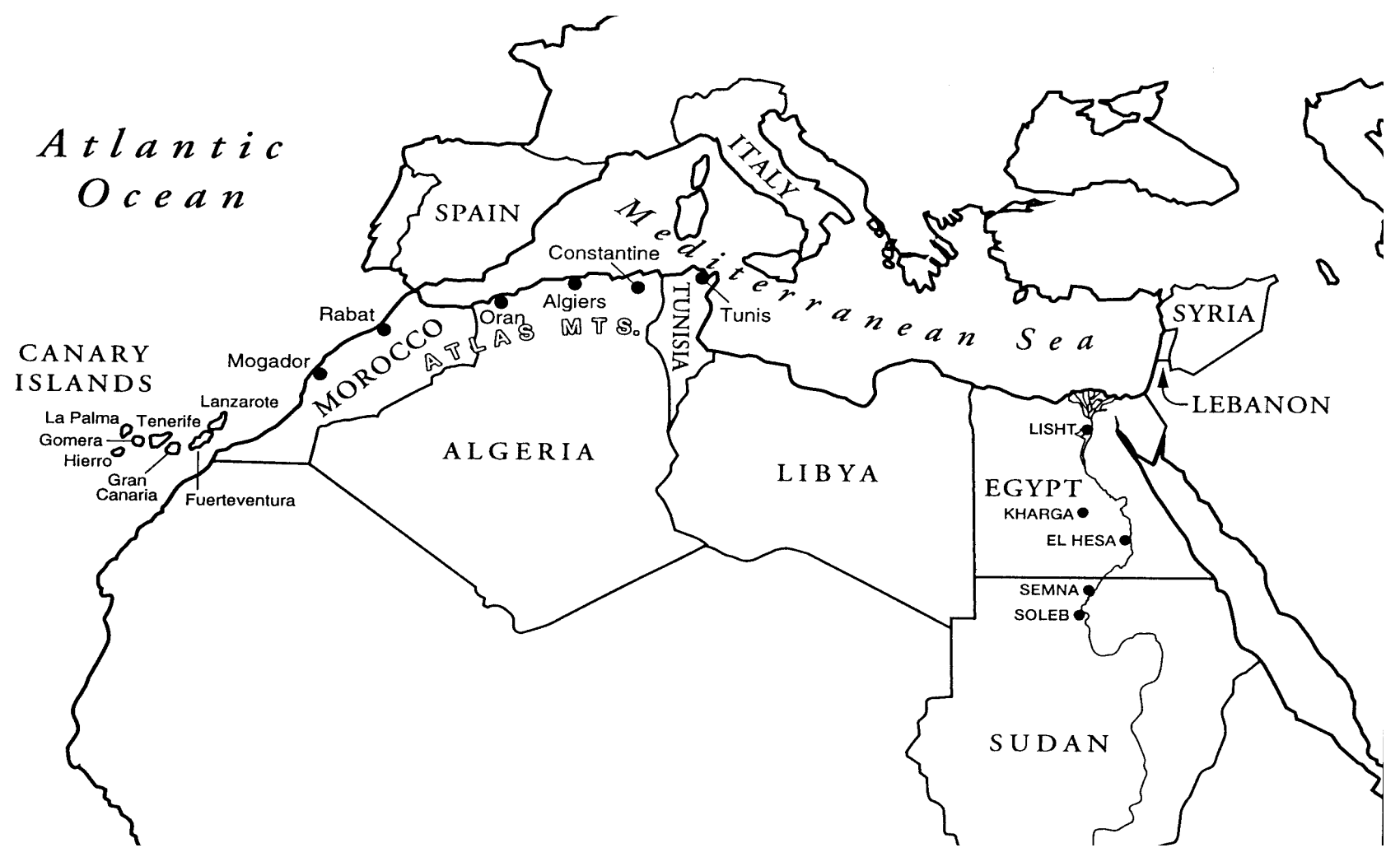

Fig. 1. Regional map showing Canary Islands, North Africa, and the Mediterranean area. 
late-arrival model. In addition, his hypothesis provides an explanation for sea transportation to the islands - an ability the Guanche apparently did not possess at the time of European Contact. However, others maintain (e.g., Cavalli-Sforza et al., 1994) that the Guanche originally sailed to the islands of their own accord, and subsequently lost the skill to make adequate sea-going vessels. Like Hooton, Mercer suggests later contact by Carthaginians and Arabs may have provided an additional genetic contribution to the Canary Island gene pool.

Despite these widely varying scenarios all workers agree that, at the time of European Contact, the native Guanche comprised a lightly-pigmented population (Murdock, 1959; Vallois, 1969) reminiscent of peoples living throughout Europe, the Mediterranean area, and parts of North Africa. This contention is based on 15th century French and Spanish accounts, in addition to the aforementioned ethnographic, serological, skeletal, and other data. Further, excluding Roberts et al. (1966), most researchers believe the Guanche were closely related to Northwest African Berbers (see Hooton, 1916; Schwidetzky, 1963; Gonzalez and Tejera, 1981; Onrubia Pintado, 1987; Bermudez de Castro, 1989); perhaps those from the Atlas Mountains region of northern Morocco and Algeria (Mercer, 1980). Support for this relationship is bolstered by recent genetic analyses (Cavalli-Sforza et al., 1994), as well as long-standing linguistic evidence that Guanche, the Canary Islander's extinct language (Bynon, 1970), shows a close affinity to the Afroasiatic Berber language (Hooton, 1916, 1925; Greenberg, 1966; Mercer, 1980). The Berber language may in turn be derived from the Late Paleolithic North African Mechta and Capsian cultures (Hiernaux, 1975; Mercer, 1980; Onrubia Pintado, 1987). However, as Hooton (1925) and Mercer (1980) note, the islands' population may have also been influenced by Arab, Roman, and Carthaginian contact prior to the 15th century Spanish occupation.

\section{ODONTOMETRIC ANALYSES}

In a preliminary study (Irish, 1993a), aspects of the four hypotheses were tested via Penrose shape analysis of tooth crown diameters in samples of pre-European Contact Canary Islanders ( $\mathrm{n}=163)$, and historic Northwest African Shawia Berbers $(n=26)$, Kabyle Berbers $(n=32)$, and Bedouin Arabs $(n=49)$. Although metric data are employed, the Penrose shape component is analogous to morphological analysis because it emphasizes differences in the form of a structure (crown form) rather than size (Penrose, 1954; Rahman, 1962; Corruccini, 1973). The results tentatively support a Canary Island/Northwest Africa link. The Guanche comparison to the Shawia and Kabyle Berbers yielded low, insignificant shape values (0.09 and 0.10, respectively), indicating a close phenetic similarity that would be expected if Berbers colonized the Islands. The magnitude of the Guanche/ Arab value is twice that of the other comparisons (0.18) and is significant
(Rahman, 1962), suggesting a more distant affinity.

The present investigation expands upon this previous odontometric study. Besides the Guanche, Berbers, and Arabs, samples of West Asian-derived Carthaginians and Northeast African Egyptians and Nubians are added. In total, 12 prehistoric through historic Northwest and Northeast African samples, comprising 669 dentitions, are analyzed and compared. Moreover, in place of Penrose, tooth size apportionment analysis (Harris and Bailit, 1988; Harris and Rathbun, 1991; Lukacs and Hemphill, 1993) is used on the odontometric data. This technique provides a more robust statistical approach that uses principal components analysis for assessing inter-sample differences in allocation of tooth size.

\section{MATERIALS AND METHODS}

\section{The samples}

The Canary Islands sample used in both the previous and present odontometric studies consists of 163 skeletal dentitions (male $=70$, female $=52$, indeterminate $=41$ ). Eight crania are from the island of La Palma, 25 from Gomera, 54 from Tenerife, 56 from Gran Canaria, 11 from Fuerteventura, and nine from unidentified locations in the archipelago. Most specimens are curated at the Musée de l'Homme, Paris, although 13 are located at the American Museum of Natural History, New York, and two are at the National Museum of Natural History in Washington, D.C. The exact date(s) of the series is unknown, but radiocarbon dating of grottoes, caves, and tumuli similar to those from which the present materials were removed range from 20 $\mathrm{BC}$ to $\mathrm{AD} 1690 \pm 70$, with a median range of AD 400-900 (Mercer, 1980; Bermudez de Castro, 1989).

The Shawia Berber sample consists of 26 historic individuals who originally lived just south of Constantine, Algeria (see Fig. 1). The sample consists of dentitions from 16 males, seven females, and three individuals of unknown sex, all from the Musée de l'Homme. Greenberg (1966) characterizes Berbers as speaking one of several dialects (e.g., Shawia) of the Berber language, which belongs to the Berber language family in the Afroasiatic superfamily. Their language also reflects influence from Phoenician, Latin, and Arabic sources (Bynon, 1970). Such heterogeneity is consistent with the fact that Berber populations, especially those from the less-mountainous regions of Algeria and Morocco, show evidence of admixture with Arabs and other intrusive peoples (i.e., Carthaginian, Greek, Roman, Spanish, Turkish, French) (Wysner, 1945).

The Kabyle Berber sample is made up of 32 historic crania (male $=21$, female $=7$, indeterminate $=4$ ) from the Algiers and Oran region of the Djurdjura Mountains in northern Algeria (Wysner, 1945). They are all curated at the Musée de l'Homme. Unlike many Berbers, the Kabyle remained isolated from the many outsiders who successively conquered lands throughout northern Africa 
beginning in $750 \mathrm{BC}$. As such, they experienced relatively little genetic admixture (Wysner, 1945). The Berbers may be indigenous to North Africa, being descended from earlier Capsian and perhaps Mechta peoples (Hiernaux, 1975; Irish, 1998a,b, 1999, 2000).

The Bedouin Arab sample $(n=49)$ is composed of a heterogeneous mix of historic crania (male $=18$, female $=24$, indeterminate $=7$ ). Thirty-six individuals were recovered from the coast of Morocco between Rabat and Mogador, ten are from Algeria between Oran and Algiers, two are from Tunis, Tunisia, and one is from the Sahel region of Libya. The latter specimen was recorded at the University of Minnesota; the rest are at the Musée de l'Homme. Arabs first entered Africa along the Suez isthmus in the 7th century, conquering Byzantine lands in Egypt and to the west. A second wave of Arabs arrived in the 11th century, when entire tribes of Bedouin immigrated from the Syrian desert (Julien, 1970; Hiernaux, 1975). These nomadic peoples are similar in physical appearance to the Berbers with whom they are heavily admixed (Julien, 1970; Hiernaux, 1975).

The Carthaginian sample is made up of 28 individuals (male $=16$, female $=8$, indeterminate $=4$ ) from the site of Carthage, north of Tunis, Tunisia. Twenty-four crania were recovered from Punic period levels (751?-146 BC) (Charles-Picard and Picard, 1968). The four remaining skulls may be from the Punic period, or are perhaps from early Roman times (146 BC-AD 435) (Wysner, 1945). All of the material is curated at the Musée de l'Homme. Carthage was founded in $c a .751$ BC by the Phoenicians, a West Asiatic people from the area now comprising Lebanon (Charles-Picard and Picard, 1968). In 146 BC, Carthage was conquered by the Romans, who remained in control until AD 435. Both the Carthaginians and Romans are thought to have had extensive contact with local Berber populations (Wysner, 1945).

The remaining seven samples, from Northeast Africa, are included in the dental analysis to help delineate Guanche affinities on a broader, geographically-oriented scale. Three samples comprise 12th Dynasty through Byzantine Egyptians (1991 BC-AD 600) (Elliot Smith and Wood-Jones, 1910; Baines and Malek, 1982) from Lisht $(n=61)$, El Hesa $(n=72)$, and Kharga Oasis $(n=26)$ in Egypt. The specimens are located at the American Museum of Natural History and National Museum of Natural History. There are several hypotheses concerning Egyptian origins; they may be non-African (i.e., West Asian or southern European) (Angel, 1972; Curto, 1972; Hiernaux, 1975; Mourant, 1983), an admixed people, with African and non-African roots (e.g., Hamid Zayed, 1981), or indigenous (White, 1970; Davidson, 1974; Trigger, 1976; July, 1992; Phillipson, 1994; Newman, 1995; Williams, 1997). Whichever the case, by the Dynastic period they were likely a heterogeneous people from the combining of many ethnic elements (Curto, 1972; Davidson, 1974). The other four Northeast samples are from Nubia, in northern Sudan. One sample consists of 18th Dynasty Pharonic Nubians (1575-1380 BC) (Trigger, 1976) from Soleb $(n=32)$; the others are Meroitic $(n=91)$, X-Group $(\mathrm{n}=39)$, and Christian $(\mathrm{n}=18)$ Nubians (100 BC-AD 1400) from Semna (Zabkar and Zabkar, 1982) (see Irish, 1993b, $1998 \mathrm{~b}$ for a more complete description of all samples). The Pharonic sample was recorded at the Musée de l'Homme; the others are curated at Arizona State University, Tempe. The origin of the Nubians is unclear; they may be locals that possess a sub-Saharan component (e.g., Greene, 1967, 1972; Carlson and Van Gerven, 1977, 1979), or are heavilyadmixed migrants from elsewhere in North Africa (Irish and Turner, 1990; Turner and Markowitz, 1990).

\section{Methods employed}

Mesiodistal and buccolingual dental crown measurements were taken by Irish on each individual's maxillary and mandibular permanent teeth (I1-M3), following the method of Moorrees (1957), with Boley gauge vernier calipers accurate to $0.1 \mathrm{~mm}$. Excessively worn or carious teeth, as well as those antimere pairs exhibiting obvious size asymmetry (most often M3s), were not measured. The degree of intra-observer measurement error was assessed by comparing replicate measurements of the left side of 25 Meroitic dentitions. The mean measurement error between sessions one month apart is $0.2 \mathrm{~mm}$; this figure is within the range noted by Wolpoff (1971). Moreover, none of the measurements are significantly different based on paired-sample t-tests.

Dimensions of teeth on the left side in each sample were used for statistical analysis because, based on paired-sample t-tests, no significant differences occurred between antimeres for any dimensions (per Hemphill, 1991; Hemphill et al., 1992; Lukacs and Hemphill, 1993). If a significant difference $(p \leq 0.05)$ would have existed, the average of the dimensions from the antimere pairs would have been used per individual to compute the sample average. In cases where a tooth on the left side was missing in an individual, the right antimere (if present) was measured to maximize sample size. The resulting 32 or fewer mesiodistal and buccolingual dental crown measurements per individual were then used to calculate mean crown diameters for use in the assessment of odontometric affinity among samples.

Tooth size apportionment analysis was conducted according to the procedures of Harris and Bailit (1988) and Harris and Rathbun (1991), as modified by Hemphill (1991). The covariance matrix of mean crown diameters for each of the 12 samples was submitted to principal components analysis to obtain component loadings. Crown diameters for each sample were multiplied by the loadings for each tooth diameter, and this product was summed across all 32 crown diameters. This methodology yielded three component scores per sample (see Lukacs and Hemphill, 1993).

The mean total crown area (MD X BL) for all 16 teeth, 
per sample, was used to assess differences in overall tooth size. If samples differed significantly in total crown area $(>5 \%)$, residual component scores were calculated for those components significantly correlated with overall tooth size. Group component scores were then submitted to cluster analysis and three-dimensional ordination. A minimum spanning tree (Hartigan, 1975) was imposed on the array of component scores for ease of interpretation of association among the individual samples. All statistical analyses were performed with SYSTAT statistical software (Wilkinson, 1990).

Ideally, odontometric research should involve separate analyses by sex. However, out of necessity, the

TABLE 1. Component loadings, eigenvalues, and variance explained for the 12 dental samples.

\begin{tabular}{|c|c|c|c|}
\hline \multirow[b]{2}{*}{ Variable } & \multicolumn{3}{|c|}{ Components } \\
\hline & 1 & 2 & 3 \\
\hline UI1MD & 0.837 & 0.078 & 0.151 \\
\hline UI1BL & 0.377 & 0.631 & 0.606 \\
\hline UI2MD & 0.960 & -0.102 & 0.090 \\
\hline UI2BL & 0.724 & 0.263 & 0.043 \\
\hline UCMD & 0.563 & 0.570 & 0.332 \\
\hline UCBL & 0.491 & 0.642 & 0.280 \\
\hline UP3MD & 0.952 & 0.021 & 0.076 \\
\hline UP3BL & 0.911 & -0.056 & 0.232 \\
\hline UP4MD & 0.730 & -0.057 & -0.424 \\
\hline UP4BL & 0.923 & -0.089 & 0.081 \\
\hline UM1MD & 0.774 & -0.066 & -0.425 \\
\hline UMIBL & 0.909 & 0.044 & 0.198 \\
\hline UM2MD & 0.777 & -0.371 & -0.312 \\
\hline UM2BL & 0.770 & -0.325 & -0.312 \\
\hline UM3MD & 0.499 & -0.661 & 0.428 \\
\hline UM3BL & 0.802 & -0.485 & 0.008 \\
\hline LI1MD & 0.737 & 0.175 & 0.235 \\
\hline LI1BL & 0.177 & 0.497 & -0.511 \\
\hline LI2MD & 0.833 & 0.216 & 0.149 \\
\hline LI2BL & 0.177 & 0.850 & -0.161 \\
\hline LCMD & 0.807 & 0.252 & -0.340 \\
\hline LCBL & 0.347 & 0.765 & -0.347 \\
\hline LP3MD & 0.817 & -0.343 & -0.010 \\
\hline LP3BL & 0.817 & -0.129 & 0.358 \\
\hline LP4MD & 0.847 & 0.051 & -0.257 \\
\hline LP4BL & 0.933 & 0.040 & -0.123 \\
\hline LMIMD & 0.844 & -0.034 & 0.207 \\
\hline LM1131 & 0.927 & 0.100 & -0.023 \\
\hline LM2MD & 0.917 & 0.055 & -0.150 \\
\hline LM2BL & 0.895 & -0.035 & -0.254 \\
\hline LM3MD & 0.781 & -0.222 & 0.207 \\
\hline LM3BL & 0.837 & 0.275 & -0.094 \\
\hline Eigenvalue & 19.147 & 4.133 & 2.462 \\
\hline Variance (\%) & 59.834 & 12.916 & 7.695 \\
\hline Total Variance & 80.445 & & \\
\hline
\end{tabular}

sexes were pooled by sample in this study. This approach follows the lead of Harris and Rathbun (1991), and Lukacs and Hemphill (1991), who report that any dental size variation between the sexes was not great enough to justify the markedly smaller sample sizes. Moreover, Hemphill et al. (1992) and Lukacs and Hemphill (1993) found that while males and females within an ethnic group differ in absolute tooth size, apportionment of tooth size is unaffected by sex dimorphism.

\section{RESULTS}

Tooth size apportionment analysis of the 12 samples' crown measurements yielded the component loadings in Table 1; component eigenvalues and percentage of the variance explained are also tabulated. The dental crown measurements themselves will be presented in a separate publication on African odontometric variation, and thus are not listed. Although six principal components possess eigenvalues greater than 1.0, the first three alone account for $80.4 \%$ of the total variance.

Component one is dominated by a general size factor, which is illustrated by the strong positive loadings for most variables (see top of Fig. 2). Nevertheless, a second factor involving relative dimensions of the teeth is also evident, as reflected by much lower loadings for buccolingual dimensions of the maxillary and, particularly, mandibular anterior teeth. In other words, high scorers along this component are characterized by generally large dentitions, with anterior teeth that exhibit long mesiodistal relative to narrow buccolingual diameters.

The second component separates samples on the basis of two criteria (see middle of Fig. 2). The first is similar to the secondary factor of component one. Anterior teeth (I1, I2, C) feature dimensional segregation, with buccolingual breadths receiving higher loadings than mesiodistal lengths; this is true for both maxillary and, especially, mandibular teeth. The second distinction involves the distal molars (M2, M3). Mandibular mesiodistal and buccolingual diameters receive fewer negative loadings than their maxillary counterparts. This difference is slightly greater for the mesiodistal than buccolingual dimensions. Thus, high scorers along component two exhibit broad buccolingual diameters among anterior maxillary and, especially, mandibular teeth relative to mesiodistal dimensions, as well as relatively large mandibular distal molars compared to their maxillary isomeres.

The loadings for component three are, at first glance, confusing. However, there appears to be a distinction in buccolingual dimensions by isomere; that is, with the exception of P4 and M2, maxillary breadths receive higher loadings than their mandibular counterparts (see bottom of Fig. 2). This is especially true for I1 and C. Thus, high scorers for component three possess maxillary teeth that are broader in their buccolingual 

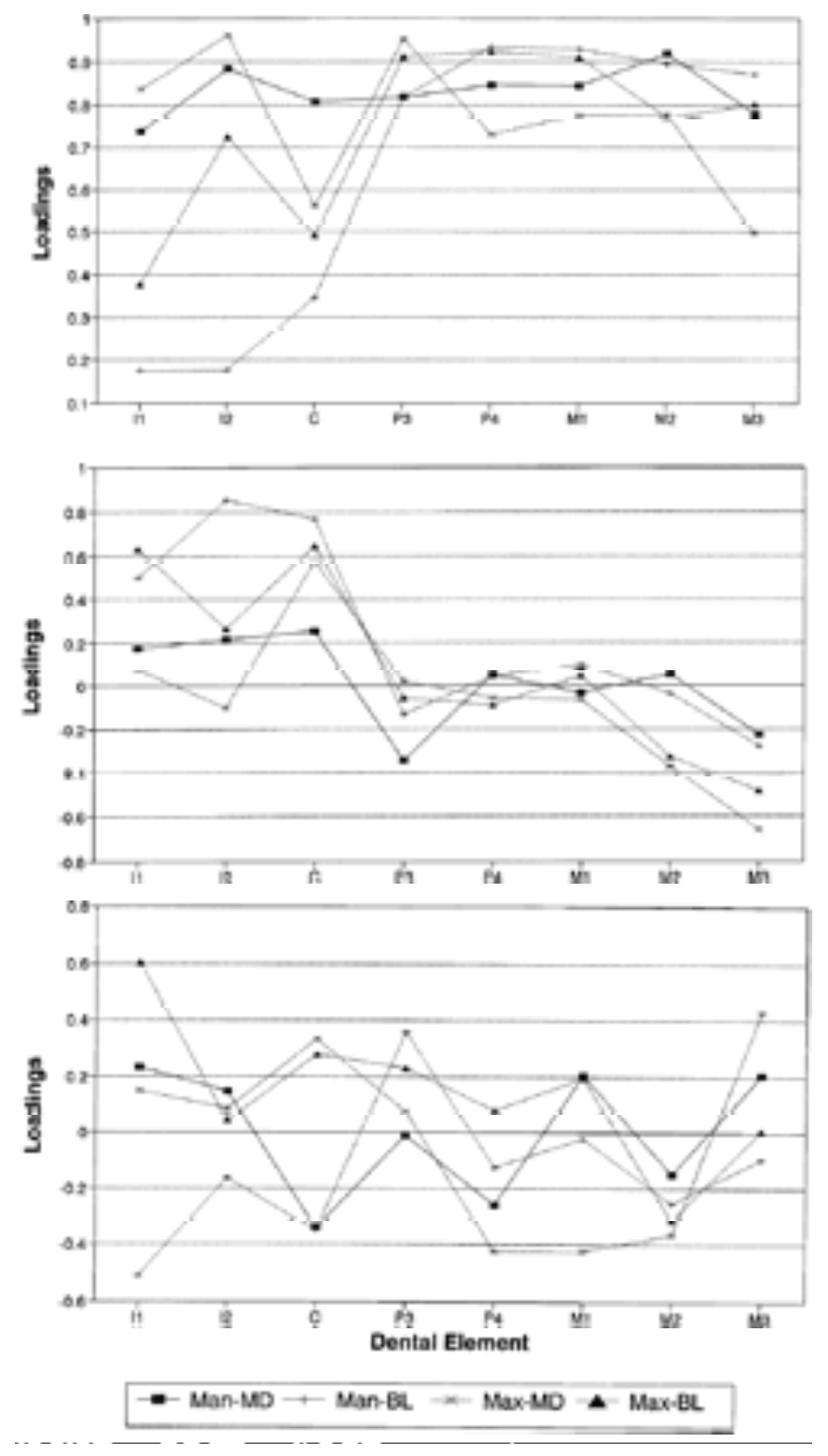

Fig. 2. Loadings among the 12 dental samples for components one, two, and three. dimensions than the corresponding mandibular isomeres.

Once component loadings were obtained, total crown areas by sample were regressed on component scores to determine if overall tooth size represents a significant contributing factor behind group scores. As is often the case, component one scores are highly associated with size (see Table 2) - in this case overall tooth size $(\mathrm{F}=1537.84, \mathrm{p}=0.00)$. However, components two and three do not show a significant association. To compensate for the effect of overall tooth size, the regression formula was used to obtain expected component one scores. Expected scores were subtracted from the observed to calculate group departures (residuals) from expected results from general tooth size.

The next step in analysis requires the use of some technique to illustrate the patterning of biological distances delineated by the residual component one, component two, and component three scores (Table 2 ). In the present investigation four methods of cluster analysis-complete linkage, single linkage, average linkage, and Ward's minimum variance, as well as three-dimensional ordination were employed.

The complete linkage dendrogram is presented in Figure 3. Results obtained with other associating algorithms produced analogous results. The Guanche sample is phenetically most similar to Northwest African Shawia Berbers, a relationship revealed by the previous Penrose analysis (Irish, 1993a). The Guanche also show a close affinity to the Carthaginian and Kabyle samples. Members of this four-group aggregate share anterior teeth of intermediate buccolingual size, and maxillary and mandibular isomeres of proportionate dimensions.

The Guanche are next most-like the aggregate at the center of the dendrogram that contains Christian, $\mathrm{X}$ Group, and Meroitic Nubians, Lisht, El Hesa, and Kharga Egyptians, and Bedouin Arabs. The earlier Penrose analysis (Irish, 1993a) also showed the Arab sample

TABLE 2. Total crown area (TCA), component scores (COMP), and residuals (RCMP) for the 12 dental samples.

\begin{tabular}{lccccc}
\hline Sample & TCA & COMP1 & RCMP1 & COMP2 & COMP3 \\
\hline Guanche & 1098.09 & -0.399 & -0.185 & 0.150 & -0.377 \\
Shawia & 1100.64 & -0.164 & 0.002 & 0.820 & -0.112 \\
Kabyle & 1117.97 & 0.125 & -0.038 & 2.001 & -0.654 \\
Bedouin & 1084.59 & -0.457 & 0.014 & -0.489 & 0.659 \\
Carthage & 1058.07 & -1.058 & -0.084 & 0.931 & -1.394 \\
Lisht & 1050.73 & -1.191 & -0.077 & -0.730 & 0.110 \\
El Hesa & 1051.15 & -1.130 & -0.024 & -0.701 & 0.865 \\
Kharga & 1086.70 & -0.624 & -0.194 & -0.508 & 0.983 \\
Soleb & 1193.56 & 1.566 & -0.043 & 1.176 & 2.012 \\
Meroitic & 1145.27 & 0.750 & 0.068 & -0.746 & 0.009 \\
X-Group & 1191.73 & 1.431 & -0.134 & -1.239 & -0.883 \\
Christian & 1177.20 & 1.162 & -0.127 & -0.664 & -1.218 \\
\hline
\end{tabular}




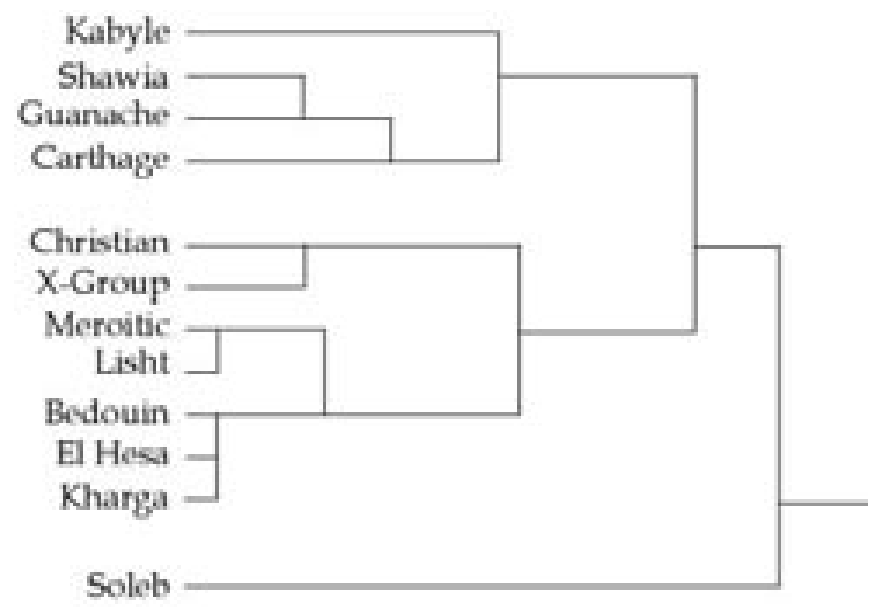

Fig. 3. Complete linkage cluster analysis dendrogram of principal component scores among the 12 samples. to be slightly divergent from the Guanche. Moreover, except for the West Asian-derived Arabs who, as noted comprise a mix of individuals from throughout North Africa, this seven-group aggregate is composed entirely of Northeast Africans. For the most part, these samples exhibit a tendency toward broad maxillary teeth relative to the corresponding mandibular isomeres. This pattern is particularly evident in the Christian and X-Group Nubian samples; they also possess relatively large teeth (see TCA in Table 2).

Lastly, the Guanche, as well as all other samples, are most divergent from Pharonic Nubians from Soleb. The Soleb sample is characterized by the largest teeth of all samples, as well as broad buccolingual anterior tooth diameters and large mandibular molars relative to the maxillary counterparts.

Similar dental relationships are illustrated by ordination of the three principal component scores (Figure 4). Axes $X, Y$, and $Z$ correspond to the sample scores for residual component one (RCMP1), component two (COMP2), and component three (COMP3). The Guanche (CAN), located on the far left of the figure, link most closely with Northwest Africans; that is,

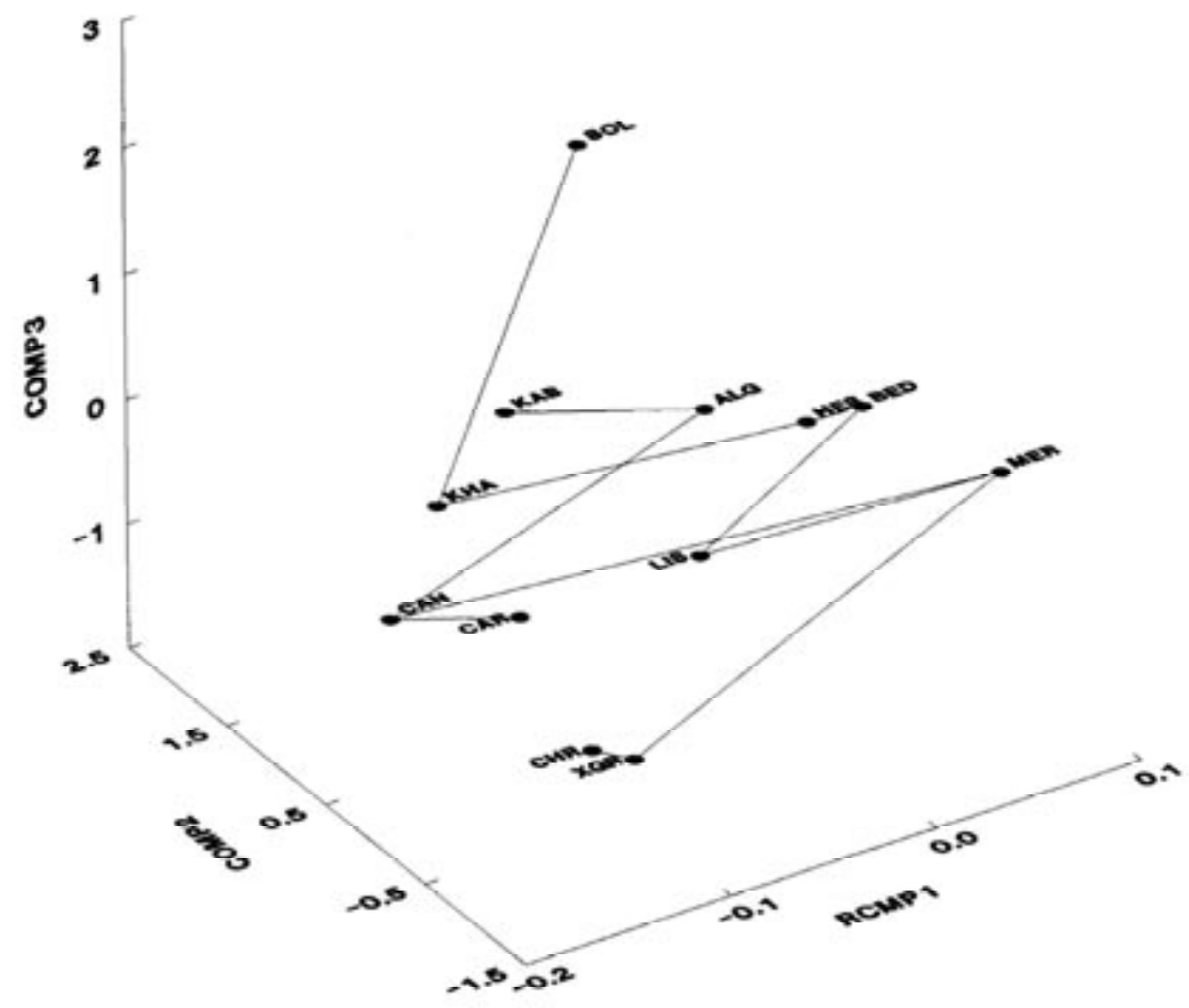

Fig. 4. Three-dimensional ordination with minimum spanning tree of principal component scores among the 12 samples. See text for explanation of abbreviations. 
with Carthaginians (CAR), Shawia Berbers (ALG), and Kabyle Berbers (KAB). However, they also exhibit some affinities to Northeast Africans. This affinity is evident by the Guanche connection to the Meroitic sample (MER) from Semna. Meroitic Nubians are in turn linked to X-Group (XGR) and Christian (CHR) Nubians, and to Lisht (LIS), the Bedouin Arabs (BED), El Hesa (HES), Kharga (KHA), and the Soleb (SOL) outlier, respectively.

\section{DISCUSSION AND CONCLUSIONS}

Although the timing and circumstances under which the immigration event(s) occurred have not been addressed by these odontometric results, tooth size apportionment analysis has revealed two important findings that pertain to other aspects of the four peopling hypotheses. First, the Canary Island Guanche show closest dental affinities to Northwest Africans, relative to other samples of various ages. Second, the pattern of phenetic affinities possessed by the Guanche suggest that some degree of biological relatedness extends beyond the adjacent mainland to Nubians and Egyptians in Northeast Africa.

The Guanche share a very similar pattern of tooth size apportionment with the Shawia and, to a lesser extent, Kabyle Berbers. This similarity corroborates results of a preliminary odontometric study (Irish, 1993a), and supports those aspects of Hooton's $(1916,1925)$, Schwidetzky's (1963), and other's (e.g., Fusté 1959, 1965; Vallois 1969) models that suggest at least some Guanche originated in Northwest Africa; it specifically sustains Mercer's (1980) and other's (e.g., Gonzalez and Tejera, 1981; Onrubia Pintado, 1987; Bermudez de Castro, 1989; Cavalli-Sforza et al., 1994) claims for a sole Berber ancestry from populations living in northern Morocco and Algeria.

Conversely, this finding cannot completely rule out Hooton's (1925), Schwidetzky's (1963), and other's (e.g., Fusté 1959, 1965; Vallois 1969, etc.) evidence for some eastern Mediterranean input, considering the Guanche affinity to most Northeast Africans. Moreover, Guanche similarity to West Asian-derived Carthaginians could be interpreted as support for this contention. However, such an affinity may simply identify evidence for Berber/Carthaginian admixture, or could imply genetic relatedness via the latter's proposed direct contact (Hooton, 1916, 1925; Mercer, 1980) with the Guanche; a similar situation might explain the slightly more distant Guanche affinity to West Asian-derived Bedouin Arabs. In addition, Hooton's (1925) suggestion for a subSaharan genetic component has not been directly tested here, although data from dental morphological studies (see Irish, 1993b, 1997, 1998a,b, 2000) do not support such a relationship. Whatever the case, the concordance of skeletal, ethnographic, linguistic, genetic, and now dental data, should put to rest any notion of a non-
African (i.e., European) origin for aboriginal Canary Islanders (as per Roberts et al., 1966).

The evidence for a lesser Guanche affinity to Egyptian and three of four Nubian samples implies aboriginal Canary Islanders belong to a greater North African gene pool. Some level of diachronic dental homogeneity apparently exists throughout North Africa - from the Canary Islands to Egypt and northern Sudan. Indeed, this east-west similarity suggests that a clinal relationship in tooth size apportionment existed, considering the separation of Northwest and Northeast African samples. These conclusions support previous findings based on dental morphological analyses published elsewhere (Irish, 1993b, 1997, 1998a,b; Guatelli-Steinberg et al., 2001).

\section{ACKNOWLEDGMENTS}

We thank the individuals at the institutions from which the Guanche and comparative data were collected, including: Christy G. Turner II, Charles Merbs, and Donald Morris from Arizona State University; Guy Gibbon and the late Elden Johnson from the University of Minnesota; Douglas Ubelaker and David Hunt from the National Museum of Natural History; Ian Tattersall, Jaymie Brauer, and Gary Sawyer from the American Museum of Natural History; Andre Langaney, Frances Roville-Sausse, and Miya Awazu Periera da Silva from the Musée de 1'Homme; Fred Wendorf and Sue Linder-Linsley from Southern Methodist University, and Henry de Lumley and Dominique GrimaudHerve from the Institut de Paléontologie Humaine. Research was supported by grants from the National Science Foundation (BNS-9013942), the Arizona State University Research Development Program, and the American Museum of Natural History.

\section{LITERATURE CITED}

Angel JL. 1972. Biological relations of Egyptian and eastern Mediterranean populations during pre-dynastic and dynastic times. J Hum Evol 1:307-313.

Baines J, Malek J. 1982. Atlas of ancient Egypt. New York: Facts On File Publications.

Bermudez de Castro JM. 1989. The Carabelli trait in human prehistoric populations of the Canary Islands. Hum Biol 61:117-131.

Bynon J. 1970. The contribution of linguistics to history in the field of Berber studies. In: Dalby D, editor. Language and history in Africa. New York: Africana Publishing Corporation, p 64-77.

Carlson DS, Van Gerven DP. 1977. Masticatory function and post-Pleistocene evolution in Nubia. Am J Phys Anthropol 46:495-506.

Carlson DS, Van Gerven DP. 1979. Diffusion, biological determinism, and biocultural adaptation in the $\mathrm{Nu}$ bian corridor. Amer Anthrop 81:561-580.

Cavalli-Sforza LL, Menozzi P, Piazza A. 1994. The his- 
tory and geography of human genes. Princeton: Princeton University Press.

Charles-Picard G, Picard C. 1968. The life and death of Carthage. New York: Taplinger Publishing Co.

Corruccini RS. 1973. Size and shape in similarity coefficients based on metric characters. Am J Phys Anthropol 38:743-754.

Curto S. 1972. Archaeological outline of Egypt from the Paleolithic to the modern Arab state. J Hum Evol 1: 141-146.

Davidson B. 1974. Africa in history. New York: MacMillan Publishing Company.

Elliot Smith G, Wood-Jones F. 1910. The archaeological survey of Nubia: Report for 1907-1908, Volume II, Report on Human Remains. Cairo: National Printing Department.

Falkenburger F. 1939. Essai d'une nouvelle classification craniologique des anciens habitants des Canaries. L'Anthropologie 49:330-364, 523-541.

Fusté M. 1959. Contribution à l'anthropologie de la Grande-Canarie. L'Anthropologie 63:295-318.

Fusté M. 1965. Physical anthropology of the Canary Islands. Am J Phys Anthropol 23:285-292.

Gonzalez R, Tejera A. 1981. Los aborigenes Canarios. La Laguna, Tenerife: Universidad de La Laguna.

Greenberg JH. 1966. The languages of Africa. Bloomington: Indiana University.

Greene DL. 1967. Dentition of Meroitic, X-Group, and Christian populations from Wadi Halfa, Sudan. Anthropol. Paper 85, Nubian Ser. 1. Salt Lake City: University of Utah Press.

Greene DL. 1972. Dental anthropology of early Egypt and Nubia. J Hum Evol 1:315-324.

Guatelli-Steinberg D, Irish JD, Lukacs J. 2001. Canary Island-North African population affinities: Measures of divergence based on dental morphology. Homo 52:173-188.

Hamid Zayed A. 1981. Egypt's relations with the rest of Africa. In: Mokhtar G, editor. General history of Africa II: Ancient civilizations of Africa. Berkeley: University of California Press, p 136-154.

Harris EF, Bailit HL. 1988. A principal components analysis of human odontometrics. Am J Phys Anthropol 75:87-99.

Harris EF, Rathbun TA. 1991. Ethnic differences in the apportionment of tooth sizes. In: Kelley MA, Larsen CS, editors. Advances in dental anthropology. New York: Wiley-Liss, p 121-142.

Hartigan JH. 1975. Clustering algorithms. New York: Wiley.

Hemphill BE. 1991. Tooth size apportionment among contemporary Indians: An analysis of caste, language, and geography. Ph.D. dissertation, University of Oregon, Eugene.

Hemphill BE, Lukacs JR, Rami Reddy V. 1992. Tooth size apportionment among contemporary Indians:
Factors of caste, language, and geography. J Hum Ecol 2:231-253.

Hiernaux J. 1975. The people of Africa. New York: Charles Scribner's Sons.

Hooton EA. 1916. Preliminary remarks on the archeology and physical anthropology of Tenerife. Am Anthropol 18:358-365.

Hooton EA. 1925. The ancient inhabitants of the Canary Islands. Cambridge: Peabody Museum of Harvard University.

Irish JD. 1993a. Dental morphometric affinity of Canary Islanders with North African Maghreb populations. Am J Phys Anthropol Supplement 16:114.

Irish JD. 1993b. Biological affinities of late Pleistocene through modern African aboriginal populations: The dental evidence. Ph.D. Dissertation, Arizona State University, Tempe. Ann Arbor: University Microfilms.

Irish JD. 1997. Characteristic high- and low-frequency dental traits in Sub-Saharan African populations. Am J Phys Anthropol 102:455-467.

Irish JD. 1998a. Diachronic and synchronic dental trait affinities of Late and post-Pleistocene peoples from North Africa. Homo 49:138-155.

Irish JD. 1998b. Dental morphological affinities of Late Pleistocene through recent sub-Saharan and North African peoples. Bull Mem Societé d'Anthropol Paris. Nouvelle serie 10:237-272.

Irish JD. 1999. Chi erano gli Iberomaurusiani? Affinità biologiche tra popolazioni Nord-Africane del Pleistocene Superiore e più recenti. Attualità dell' Antropologia Ricerca e Insegnamento nel XXI secolo, $p$ 113-114.

Irish JD. 2000. The Iberomaurusian enigma: North African progenitor or dead end? J Hum Evol 39: 393-410.

Irish JD, Hemphill BE. 2001. Les Canaries ont-elles été colonisées par les Berbčres d'Afrique du Nord? La contribution de l'analyse odontométrique. In: Hadjouis D, Mafart B, editors. La paléo-odontologie: Analyses et méthodes d'étude. Collection paléoanthropologie et paléopathologie osseuse. Paris: Artcom, p 122-137.

Irish JD, Turner CG II. 1990. West African dental affinity of late Pleistocene Nubians: Peopling of the Eurafrican-South Asian triangle II. Homo 41:42-53.

Julien C. 1970. History of North Africa. London: Routledge and Kegan Paul.

July RW. 1992. A history of the African people, 4th edition. Prospect Heights, Ill: Waveland Press. Lukacs JR, Hemphill BE. 1991. The dental anthropology of prehistoric Baluchistan: A morphometric approach to the peopling of South Asia. In: Kelley MA, Larsen CS, editors. Advances in dental anthropology. New York: Wiley-Liss, p 77-119.

Lukacs JR, Hemphill BE. 1993. Odontometry and 
biological affinity in South Asia: Analysis of three ethnic groups from Northwest India. Hum Biol 65: 279-325.

Mercer J. 1980. The Canary Islanders: Their prehistory, conquest and survival. London: Rex Collings.

Moorrees CFA. 1957. The Aleut dentition: A correlative study of dental characteristics in an Eskimoid people. Cambridge: Harvard University Press.

Mourant AE. 1954. The distribution of the human blood groups. Springfield, IL: Charles C. Thomas, Publisher.

Mourant AE. 1983. Blood relations: Blood groups and anthropology. Oxford: Oxford University Press.

Murdock GP. 1959. Africa: Its peoples and their culture history. New York: McGraw-Hill.

Newman JL (1995) The peopling of Africa: A geographic interpretation. New Haven: Yale University Press.

Onrubia Pintado J. 1987. Les cultures préhistoriques des Îles Canaries état de la questions. L'Anthropologie 91:653-678.

Penrose LS. 1954. Distance, size and shape. Ann Eugenics 18:337-343.

Phillipson DW. 1994. African archaeology, 2nd ed. Cambridge: Cambridge University Press.

Rahman NA. 1962. On the sampling distribution of the studentized Penrose measure of distance. Ann. Hum. Genetics 26:97-106.

Roberts DF, Evans M, Ikin EW, Mourant AE. 1966. Blood groups and the affinities of the Canary Islanders. Man 1:512-525.

Trigger BG. 1976. Nubia under the pharaohs. Boulder, CO: Westview Press.

Turner CG II, Markowitz M. 1990. Dental discontinu- ity between late Pleistocene and recent Nubians. I. Peopling of the Eurafrican-South Asian Triangle. Homo 41:42-53.

Schwidetzky I. 1963. La población Prehispánica de las Islas Canarias. Santa Cruz de Tenerife: Museo Arqueologico de Tenerife.

Vallois HV. 1969. Les hommes de Cro-Magnon et les Guanches: Les faits acquis et les hypothèses.

Simposio de Cro-Magnon. Anuario de Estudias Atlanticos. Madrid 15:97-119.

Verneau R. 1887. Rapport sur une mission scientifique dans l'archipel Canarien. Archives des Missions scientifieques et littéraires, 3e série 13:569-817.

Verneau R. 1891. Cinq années de séjour aux îles Canaries. Paris.

White JEM. 1970. Ancient Egypt: Its culture and history. New York: Dover Publications, Inc.

Williams B. 1997. Egypt and Sub-Saharan Africa: Their interaction. In: Vogel J, editor. Encyclopedia of precolonial Africa: Archaeology, history, languages, cultures, and environments. Walnut Creek: Alta Mira Press, p 465-472.

Wilkinson L. 1990. SYSTAT: The system for statistics. Evanston, IL: Systat, Inc.

Wolpoff MH. 1971. Metric trends in hominid dental evolution. Studies in Anthropology, no. 2. Cleveland: Case Western Reserve University Press.

Wysner GM. 1945. The Kabyle people. New York: Privately Printed.

Zabkar LV, Zabkar J. 1982. Semna South. A preliminary report of the 1966-68 excavation of the University of Chicago Oriental Institute expedition to Sudanese Nubia. J Am Res Center Egypt 19:21-28. 